\title{
HOUSING REHABILITATION PROGRAM FOR POOR FAMILIES IN SUBURBAN AREAS: EVALUATION OF THE REGULATION OF THE SOUTH BARITO REGENT \#8 OF 2015
}

\author{
Trisnanto Karunia Ardhi ${ }^{*}$, Saleh Choirul, Haryono Bambang Santoso \\ Master's Program of Public Administration, Faculty of Administrative Science, \\ University of Brawijaya, Indonesia \\ *Email: ardhibarsel@gmail.com
}

\begin{abstract}
Poverty is a social issue that continuously challenges the government of Indonesia to find its solution. Since the enactment of regional autonomy, anti-poverty programs should not only run by the central government, but they are also under the responsibility of both provincial government as well as district government. The government of Central Kalimantan runs an anti-poverty program namely Mamanguri Tuntang Mahaga Lewu (PM2L) which puts the improvement of basic facilities into the priority including the housing rehabilitation program. In order to implement the program, the government of South Barito has arranged a technical guideline to run the program as stated in the Regulation of South Barito Regent \#8 of 2015 about the Guideline of Housing rehabilitation Program for Poor Families in Suburban Areas PM2L of 2015. This evaluation study is a descriptive study, employing a qualitative research approach. The result of this study shows that the program has not yet optimally administered since there was no certain standard operating procedure available and some activities were not done within the arranged schedule. Fortunately, the result of the housing rehabilitation program has been considered optimal for it has fulfilled all of the criteria set in this study. The program has brought direct effect - rehabilitated poor families' houses, and indirect effect - improving the neighborhood's awareness to help each other. Besides, the families were required to provide some additional money to rehabilitate their houses.
\end{abstract}

\section{KEY WORDS}

Policy evaluation, housing rehabilitation, poor families, suburban areas, PM2L.

Poverty continuously appears as a social issue that needs solution from the government of Indonesia. Amatya Sen (in Anggraeni, 2009) stated that poverty should not be seen only from the low income earned by the people since poverty refers to a condition in which a family is unable to provide the basic necessities to fulfill the basic function in a society. It implies that poverty includes low income to fulfill the proper food, clothes, and house, and inability to afford health service, proper education, political participation or any social function.

Based on the data released by the Central Bureau of Statistics (2015), Indonesia has its number of population increased from 238.5 millions people in 2010 to 255.5 millions people in 2015 with population growth rate of $1.38 \%$. One of the negative impact of the large population is the poverty. The poverty affects some aspects of life which eventually determine the quality of the human development including the education, health care, and welfare which include housing problems in Indonesia.

Generally, the need of housing program in Indonesia increases as the population grows larger, increasing the need of houses in every yet. Based on the report of the Budget Analysis and Implementation Bureau, APBN-SETJEN DPR-RI, the average number of the need of home is 930 units each year. Meanwhile, the capacity of the program has not yet been able to keep up with the growth. The central of Statistics Bureau in 2014 released the data of Indonesian backlog which was estimated to reach 17.2 millions units. In line with the statement of Suyanto (2015), the anti-poverty program has not yet been able to provide satisfying progress.

Since the enactment of regional autonomy, anti-poverty program is run by not only the central government, but also the regional government, especially in implementing the 
housing rehabilitation program. In order to implement the housing rehabilitation program, the government of South Kalimantan created a program namely PM2L which focuses on improving the basic facilities including the housing rehabilitation program. The government of South Barito District has arranged the guidelines of PM2L implementation that covers improvements of basic facilities, education access, health care services, society welfare, and society development. The housing rehabilitation belongs to the sub program of the improvement of basic facilities program that provides housing service for poor families in suburban areas.

The budget for housing rehabilitation program in 2015 is as much as 600.000 .000 rupiahs which is higher than previous years. This study focuses on the implementation of the housing rehabilitation program for poor families in 2015. The legal basis of this program implementation is the Regulation of South Barito Regent Number 8 of 2015 about the Guidelines of the housing rehabilitation program for poor family which is funded from the regional budget of South Barito District within the list of the Social Development and Suburban Government agenda or Badan Pemberdayaan Masyarakat dan Pemerintahan Desa (BPMPD).

Evaluation of a program should be initialized by the determination of problems that occurred during the implementation. There have been a number of problems that occurred in the implementation of housing rehabilitation program in South Barito 2015 including the uneven distribution of the aids to poor families in South Barito District and relatively small amount of money that was not yet enough to rehabilitate a house.

Based on the reasons above, it was necessary to conduct this study that intended at evaluating the housing rehabilitation program for poor families in South Barito. Regarding to the explanation, this study entitled "Evaluation of Housing rehabilitation Program for Poor Families in Suburban Areas (Evaluation Study on the Regulation of South Barito Regent Number 8 of 2015 about the Guidelines of Housing rehabilitation Program for Poor Families in Suburban Areas Mamangun Tuntang Mahaga Lewu in South Barito 2015)".

Evaluation is a part of a policy making steps which are identification, implementation and evaluation. Without evaluation, the condition of an object before and after the implementation remains unknown. Tague-Sutclife (1996) identified evaluation as "a systematic process of determining the extent to which instructional objective are achieved by pupils". Evaluation is not merely an activity to spontaneously and incidentally score an activity, but it is also an activity to conduct a well-planned and systematic assessment with clear objectives.

In line with Nawawi (2009), evaluation refers to an activity to assess the success or failure of an organization or a unit in implementing their programs and functions.

\section{METHODS OF RESEARCH}

This study is a descriptive research using a qualitative approach. This study was conducted in BPMPD of South Barito District and in the houses of the poor families who received the housing rehabilitation program. The focuses of this study included: (1) the implementation process of the housing rehabilitation program as a public policy for poor families in South Barito 2015 which was assessed based on the criteria proposed by Widodo (2009) which are: (a) interpretation, (b) organization, and (c) application. (2) Result of the housing rehabilitation for poor families in suburban areas in South Barito 2015 evaluated using the evaluation model proposed by Dunn (2003) which included six criteria; effectiveness, efficiency, sufficiency, balance, responsiveness, and accuracy. (3) the effect of the housing rehabilitation implementation seen from factors proposed by Anderson in Islamy (2014) which included the intended consequences and unintended consequences. The data were obtained and analyzed based on some steps proposed by Miles, Huberman and Saldana (2014) including the data collection, data condensation, data display, conclusion drawing and verification. 


\section{RESULTS AND DISCUSSION}

The implementation of housing rehabilitation for poor families in suburban area of South Barito in 2015. In the interpretation stage, deeper review on the Regional Regulation of Central Kalimantan Number 13 of 2005 about the Medium-Term Development Planning Year 2006-2010 which was then put into the managerial procedure in the Regulation of South Barito Regent Number 8 of 2015, The Letter of Decision of the South Barito Regent Number 99 of 2015, and the Letter of Decision of South Barito Regent Number 291 of 2015. The operational procedure was explained in the Decision of the Head of BPMPD South Barito number 414.2/366/BPMPD/2015 in which a technical team planner was appointed and the letter number 414.2/367/BPMPD/2015 explained the function of data verification team to collect the data related to the poor families that would receive the housing rehabilitation aids.

The organization stage consists of (a) policy implementation, in the Regulation of South Barito Regentu Number 8 of 2015 in which it is stated that the person in charged of this function is BPMPD of South Barito as implied in the Article 3 verse (1). The housing rehabilitation program is under the responsibility of the Department of Organization and Development of Society Participation of BMPD as stated in the Letter of Decision of South Barito Regent Number 199 of 2015 about Appointment of Coordinator Team and The Committee of Housing rehabilitation Program Mamangun Tuntang Mahaga Lewu of South Barito Number 8 of 2015. Therefore, those documents were used as the guidance and reference in implementing the program.

The standard operating procedure (SOP) of this program was not yet available. However, the indicators of the performance in the implementation of this program have been arranged in the work plan of BPMD of South Barito in 2015. It can be seen from the data that the indicators of the program have been achieved. (c) Funding Source and Facilitation, this program is funded from the regional budget of South Barito. The budget was used to fund all of the activities related to the housing rehabilitation program for poor families in suburban areas. Therefore, BPMPD has fulfilled the duty to fund the program which was the main source to run the program.

The budget for this program in 2015 was arranged as much as $R p$ 600.000.000,which has been distributed to fund rehabilitation program for 76 poor families, in which each family received different amount of money based on the condition of the houses. The condition of the houses was categorized into three categories; Rp 3.000 .000 to $R p$ 4.000.000 for slight damage, Rp 7.000.000 for moderate damage, and 10.000.000 - Rp 14.000.000 for severe damage. The fund played a major role in running this program and to achieve the goals of this program.

Another important factor is the facilitation. Sufficient facilities improve the effectiveness and the efficiency in running the program. The tools needed to repair the house were not provided by BPMPD, instead BPMPD provided materials and money to repair the houses which were given to the head of the village. Thus, the families should provide the tools themselves. (d) Appointing the executors of the policy. In this step, the executors were appointed and they created certain leadership pattern and coordination procedure in implementing this program. In this context, the leadership pattern only involved the intern management of BPMPD. The head of BPMPD functioned as the manager. Thus, the leadership pattern was the top up pattern. Therefore, the executors should report their work to the head of BPMPD. (e) scheduling. Housing rehabilitation program was suppored to start in April 2015 and end in December 2015 as scheduled in the regulation. However, the implementation delayed from the schedule.

In the application stage, the arranged housing rehabilitation program was implemented. In this state, all of the scheduled actions were administered (Widodo: 2016).

The result of the housing rehabilitation program for poor families in suburban areas of South Barito District in 2015. In 2015, BPMPD of South Barito has administered the housing rehabilitation program for poor families in suburban areas $P M 2 L$. This program was funded by the regional budget of South Barito in 2015 through the work plan of BPMPD South 
Barito. The program spent $\operatorname{Rp} 600.000 .000$,- to repair 76 houses of poor families which fund was distributed through the headman of the villages.

This program was administered by distributing certain amount of money for poor families to repair 76 families' houses. The amount of the money given to the family depended on the condition of the house which was categorized into slight damage, moderate damage, and severe damage. Thus, this program did not directly repair the houses, yet it indirectly repair the houses by providing the fund. The result of this study shows that this program has been effectively implemented seen from the success of the program in achieving the goals; rehabilitating old houses of poor families. This program is also a part of anti-poverty program since residence is one of the human's basic necessities.

Efficiency of the housing rehabilitation program can be seen from how optimum the program solves the problems and how it fulfills the necessities of the poor family. Dunn (2003) stated that efficiency refers to the amount of effort that should be made to achieve certain level of effectiveness. In addition, a policy is said efficient if its effectiveness can be achieved from spending least amount of fund. Thus, the efficiency of the housing rehabilitation program can be measured from the resources indicator and optimization. Resources refer to the quality and the quantity of the human as well as the facilities available to support the implementation of the housing rehabilitation program. Whilst, optimization refers to the process on how to achieve the best result out of an action.

Based on the explanation above, it can be understood that attempt to ensure the quality and the quantity of the human resource for this program was made by appointing eight coordinators and nine managers to administer the program. Related to facilitation, poor families were given some fund to repair their houses. Optimization was done by giving the aid in the form of money in order to let the families repair their houses according to their own needs. Regarding Dunn's (2003) view on the correlation between effort and effectiveness, the indicators stated above can be regarded as the real effort to achieve the goal of the program.

Housing rehabilitation program for poor families in South Barito District is one of antipoverty actions. Based on the data released by the Central Bureau of Statistics, out of 131.987 people who lived in South Barito, 6.600 people or $5.07 \%$ of the population were considered poor. From this number, 76 heads of poor families were chosen to receive the fund to repair their houses. The sufficiency of the fund can be measured from three indicators. The first indicator is the executors' performance. Executors team consisted of coordinators, secretariat, technical executors and manager team. Those teams have done their jobs based on the guideline stated in the Decision Letter of South Barito Regent and the Decision Letter of the Head of BPMPD South Barito.

Secondly, sufficiency is also related to the amount of the fund used in the implementation of the housing rehabilitation program. The fund for this program was taken from the regional budget of South Barito in 2015 through BPMPD of South Barito as much as Rp $600.000 .000,-$. The fund was then distributed to 76 poor families through the headman of the village. The amount of the money given to each family was determined based on the condition of the houses which were categorized into slight damage (18 families), moderate damage (22 families) and severe damage (36 families).

The last indicator of the sufficiency was the solution determined to solve the problem that occurred. In this case, the housing rehabilitation program is regarded as a solution to the poverty, and it is also a part of the anti-poverty program. Hence, it can be stated that $P M 2 L$ program run by the government of South Barito as a part of infrastructure development has given some positive contributions and benefits for poor families, and it successfully solved some problems that occurred.

Each policy made by any government including the regional government of South Barito should be oriented to the public interests and fulfills the principle of equity and justice. As stated by Dunn (2003), policy that is oriented to public interest and equity can be in the form of policies that deal with public service and monetary which are fairly distributed.

The target of the housing rehabilitation program is to provide fund to rehabilitate improper houses of poor families. In 2015, Rp 600.000.000,- of the regional budget was 
used to fund the program. Houses with slight damages received $\mathrm{Rp} 3.000 .000$ to $\mathrm{Rp}$ 4.000.000 (18 families), moderate damages Rp 7.000.000 (22 families) and severe damage Rp 10.000.000 to Rp 14.000.000 (36 families). Therefore, this program has provided benefits for 76 families in South Barito.

The success of a program is also determined by the responses of the society toward the program. Dunn (2003) explained that responsiveness refers to how good a program satisfies the necessities, preferences, and values of certain groups. In this study, five informants expressed their satisfaction and positive responses toward the housing rehabilitation program run by the government of South Barito in 2015. In line with Dunn (2003), a polity should be able to satisfy and meet the needs, preferences and values of certain society.

The housing rehabilitation program which was done by the government of South Barito District to repair the houses of poor families is a part of $P M 2 L$ program held by the Municipal Government of Central Borneo. Accuracy is the last success criteria which can be measured from the goal of certain program as a solution to solve certain problem that occurred within a society. Accuracy is the measurement whether a program successfully solved a problem or it triggered some other problems. As explained by Dunn (2003), accuracy has a close correlation with substantive rationale since accuracy deal with not only individual criteria but also two or more criteria at the same time.

The accuracy of the housing rehabilitation program for poor families in suburban areas is a solution to solve problems that occurred among poor society. The regulation of this program explains technical procedure in implementing the program. The regulation was made to make sure that the program funded by the regional budget of South Barito District implemented in the most effective, efficient, economical and accurate way.

76 people were selected to receive the aids based on the data verification and survey done by the verifiers. In another word, not all of poor families in South Barito received the fund since the amount of the fund was also limited. It can be concluded form the selection process, 76 people who received the aid have been accurately selected.

The effects of the housing rehabilitation program for poor families in South Barito in 2015. The housing rehabilitation program has rehabilitated 76 houses of poor families in South Barito. The aids were distributed in the form of fresh money which amounts were determined based on the condition of the houses.

Jealousy from the neighbors arose as an indirect effect because the neighbors also expected to receive similar aids. The second issue is related to the insufficient amount of money received by the families that forced them to provide some additional money of their own to repair their houses. Another effect is the fact that the program enhanced mutual cooperation in the society since they worked together and helped repairing the houses. The neighbors usually sacrifice their time and money to cut off some expenses to pay for some handyman.

\section{CONCLUSION}

The housing rehabilitation program for poor families done by the government of South Barito District was not yet optimally administered due to the absence of the standard operating procedure and some agendas were not conducted as scheduled. Despite of several minor shortcomings in the implementation of the program, overall, the program was successfully implemented in accordance with the regulation of South Barito Regent Number 8 of 2015.

The implementation of the program has fulfilled all of the predetermined criteria. The outcome of the program can be seen from the result of the rehabilitation done to 76 houses of poor families in suburban areas in six regencies. As much as IDR 600,000,000 were spent from the regional budget of South Barito District to fund the program. The amount of money given to the receivers differed based on the damages on the houses; IDR 3,000,000 to IDR $4,000,000$ for slight damage (18 families), IDR 7,000,000 for moderate damage (22 families) and IDR 10,000,000 to IDR 14,000,000 for severe damage (36 families). 
The housing rehabilitation has given a direct effect in which 76 houses of poor families in South Barito District in 2015 were repaired. This appears as a positive effect. Another positive effect appeared as the neighbors participated in repairing the houses which enhanced the mutual cooperative among the society. However, jealousy from the neighbors also arose as a negative impact. Besides, the poor families were also required to add some money on their own to repair the houses.

Regarding to the result of this study which has been presented in the previous section, suggestions are directed at BPMPD of South Barito District as follows.

It is recommended that yearly program is arranged in such way that the projects have high relevancy to each other.

Standard operating procedure needs to be created in order to provide clear instructions in implementing the program.

Coordination among the teams has to be enhanced in order to improve the punctuality of the team. Hence, the program can be administered according to the predetermined schedule in the regulation of South Barito District Number 8 of 2015.

If the program continues next year, it is expected that higher amount of fund should be given to the poor families. Thus, more people can receive the aids. However, if this program is terminated in next year, the government should allocate the budget to open more jobs and increase the standard of regional minimum wages instead of running the program that creates social jealousy and unfairness among the society.

\section{REFERENCES}

1. Anggraeni, Ayu Dian. 2009. Faktor Kemiskinan dan Faktor Determinan Kemiskinan di Kabupaten Bogor. Studi kasus Desa Jogjagon, Cisarua Bogor. Tesis Fakultas Ekonomi Universitas Indonesia. Universitas Indonesia. Jakarta.

2. Badan Pusat Statistik (BPS). 2015. Statistik 70 Tahun Indonesia Merdeka. CV. Dharmaputra. Jakarta. https://www.bps.go.id/

3. Biro Analisa Anggaran dan Pelaksanaan APBN-SETJEN DPR-RI. Pembangunan Perumahan. (http://berkas.dpr.go.id/setjen/dokumen/biro-apbn-apbn-PembangunanPerumahan-1434526946.pdf di akses 29 Maret 2017)

4. Dunn, William. 2003. Pengantar Analisis Kebijakan Publik. Gadjah Mada University Press. Yogyakarta. Terjemahan.

5. Islamy, Irfan. 2014. Prinsip-Prinsip Perumusan Kebijaksanaan Negara. Cetakan Keenam belas. Bumi Aksara. Jakarta.

6. Miles, Metthew B, A, Michael Huberman and Johny Saldana. 2014. Qualitative Data Analysis, A Methods Sourcebook. Third Edition. Sage Publication, Inc.

7. Suyanto, Bagong. 2015. Anatomi Kemiskinan dan Strategi Penanganannya. In-TRANS Publishing. Malang.

8. Widodo, Joko. 2016. Analisis Kebijakan Publik, Konsep \& Aplikasi Analisis Proses Kebijakan Publik. Malang: Bayumedia. 